\title{
Paternidade de Deus e mistério trinitário no ensino de Paulo VI e João Paulo II
}

\author{
God's paternity and Trinitarian mystery \\ in the teaching of Paul VI and John Paul II
}

Marcial Maçaneiro

\section{Resumo}

Neste artigo, vem exposto o magistério de Paulo VI e João Paulo II sobre a paternidade de Deus e sua relação com o mistério trinitário, considerando as afirmações explícitas de ambos sobre o tema. O recorte temático inclui encíclicas, exortações apostólicas, catequeses e locuções. Com enfoque sistemático, examinam-se os enunciados sobre Deus Pai (sua revelação e seu sentido), esclarecendo também as conexões deste tema com o mistério trinitário, nos dois pontífices. A análise qualitativa dos textos permite ordenar os conteúdos do ponto de vista dogmático, bem como estabelecer uma aproximação comparada entre os dois Papas, cujo magistério situa-se no arco cronológico que vai do Concílio Vaticano II ao Grande Jubileu do Ano 2000. Deus Pai desponta como mistério (na intimidade da vida trinitária) e revelação (na economia da historia salutis), referido ao Filho-Verbo e ao Espírito-Sopro. Tanto Paulo VI quanto João Paulo II ensinam à luz do mistério trinitário, atentos à centralidade de Jesus na revelação do Deus Pai. Sob tal luz, os dois Papas oferecem elementos relevantes para a compreensão teológica do Filioque e para a universalidade da salvação, da qual o Pai é primus fons (fonte primeira).

Palavras-chave: Deus Pai. Trindade. Revelação. Espírito Santo. Salvação. 


\begin{abstract}
In this paper, Author presents the teaching of Paulo VI and John Paul II on divine paternity and its relation with the mystery of the Holy Trinity, considering the explicit affirmation of two Pontiffs on the matter. The thematic research includes encyclical letters, apostolic exhortations and messages. In a systematic way, Author examines the Popes' affirmation on God the Father (His revelation and meaning) and His ties with Trinitarian faith as well. The qualitative analysis of the texts permits Author to explain the contents in a dogmatic perspective, and to achieve a comparative approach of two Popes, whose teachings cover the period from 2 Vatican Council to the 2000 Year Jubilee Celebration . God the Father is presented by them as mystery (in the Trinitarian life of Deity) and revelation (through the Historia Salutis), always referred to the Son-Word and to the Spirit-Pneuma. Both Paulo VI and John Paul II teach in light of the mystery of Holy Trinity, paying attention to the central role of Jesus in God's revelation. In such light, Paul VI and John Paul II offer some remarkable elements to theological debate on Filioque and to the universal salvation plan, that has in God the Father its primus fons (the very first source).
\end{abstract}

Keywords: God the Father. Holy Trinity. Revelation. Holy Spirit. Salvation.

\title{
Introdução
}

Paulo VIe João Paulo II assinam o magistério da Igreja no arco cronológico que vai do Concílio Vaticano II ao Grande Jubileu do Ano 2000, somando aproximadamente 35 anos. Neste período, publicaram seus documentos mais importantes, bem como alocuções e catequeses significativas. Distintos no estilo e nos temas tratados, ambos se remetem ao Concílio Vaticano II e nos oferecem farto material de estudo, seja histórico, seja dogmático. Com o reconhecimento de sua exemplaridade teologal (o primeiro, bem-aventurado; o segundo, já canonizado) e as releituras do Concílio, nos pareceu oportuno traçar alguns estudos teológico-comparados desses pontífices, com foco no primeiro artigo da fé: "Creio em Deus Pai onipotente" (DZ 1)․ De um lado, temos a proclamação da paternidade de Deus, revelada na história da salvação;

\footnotetext{
${ }^{1}$ DENZINGER, H. Enchiridion symbolorum: magisterio della chiesa. $37^{\mathrm{a}}$ ed. Bologna: EDB, 1995 (sigla DZ).
} 
de outro, as implicações desta mesma paternidade nas relações trinitárias. Isto, para nos fixar especialmente nas questões básicas do dogma trinitário, já que outras abordagens são também possíveis, demandando, eventualmente, outros artigos.

Assim, nosso recorte temático é o nexo entre a paternidade de Deus e o mistério trinitário nas afirmações de Paulo VI e João Paulo II. Temos presente tanto os pronunciamentos maiores (encíclicas e exortações apostólicas), quanto os pronunciamentos menores (alocuções, mensagens, catequeses), na medida em que se incluem neste recorte. Para tanto, efetuamos leitura qualitativa das fontes, mediante análise teológica dos enunciados dos dois pontífices, para individuar e dispor suas afirmações, de modo sistemático e comparado. Embora façamos menção de alguns teólogos, conforme o argumento posto, nossa abordagem prioriza a voz dos autores. Isto se mostra ainda na disposição dos tópicos, que reflete as tematizações dos dois Papas. Com exceção dos Insegnamenti di Paolo VI e das Catequeses de João Paulo II, reunidos em volumes e/ou disponíveis online, os demais documentos são indicados por siglas (com suas referências completas ao rodapé, a cada primeira citação) ${ }^{2}$. À conclusão, pontuamos a relevância do tema em Paulo VI e João Paulo II para a reflexão teológica recente.

\section{Deus Pai em sentido ontológico}

Professar a Deus como Pai, para a fé cristã, não é artifício de linguagem, nem simbolização didática para falar de Deus convenientemente. Embora tocando "às apalpadelas" (At 17,27) o mistério divino, a Revelação nos permite crer na paternidade de Deus em sentido ontológico, referida ao ser de Deus em Si e nas suas relações. Paulo VI assevera esta abordagem, afirmando que "o Criador não é uma potência anônima e longínqua: ele é Pai" (EN 26) 3 . Sua paternidade não é mitológica ou metafórica, resultado de uma projeção indevida da parte dos humanos, mas uma "verdade ontológica"4. Porquanto "Deus é Pai eternamente, gerando em Si mesmo o Filho, seu próprio

\footnotetext{
${ }^{2}$ No caso das edições estrangeiras, todas as traduções para o português são nossas.

${ }^{3}$ PAULO VI. Exortação apostólica "Evangelii nuntiandi”. 9a ed. São Paulo: Loyola, 1979 (sigla EN).

${ }^{4}$ PAOLO VI. "Il natale di Gesù, rivelazione della paternità di Dio". In: Insegnamenti di Paolo VI, vol. XII. Roma: TPV, 1974, p. 13.
} 
Pensamento vivente, o seu Verbo idêntico na natureza - isto é, no Ser - ao Deus único Princípio absoluto"s.

A paternidade divina é, portanto, um "conceito existencial, metafísico, único, original e inefável, fonte de nossa religião" . Notemos que, embora Paulo VI mencione aqui um "conceito", os adjetivos caracterizam sua realidade e veracidade, enquanto revelação do ser de Deus (= metafísico e inefável), que incide em nossas vidas (= existencial) como elemento próprio e originário da fé cristã (= fonte de nossa religião). Sobre isto, João Paulo II acrescenta uma perspectiva claramente trinitária:

Em virtude de seu ser amor, Deus, ainda antes da livre criação do mundo, é Pai na própria vida divina: Pai amante que gera o Filho amado e, como Ele, dá origem ao Espírito Santo, a Pessoa-Amor, vínculo recíproco de comunhão. ${ }^{7}$

Anuncia-se aqui a paternidade divina na imanência da Trindade, como exposto em tópico mais adiante.

\section{Deus Pai em sentido salvífico}

Quanto à paternidade de Deus manifesta nos eventos salvíficos, Paulo VI usa a expressão salutis colloquium e põe toda a história da salvação sob o signo da auto-comunicação do Pai em Jesus Cristo (cf. ES 42) ${ }^{8}$. O Pai que eternamente comunica seu amor ao Filho no Espírito, decidiu abrir aos homens o diálogo da salvação, derramando sobre nós o mesmo amor comunional que reinava na intimidade trinitária. Paulo VI fala claramente da "iniciativa" do Pai em "travar conversação com o homem" (ES 41). Desta conversação provém o dom da vida, da aliança, das profecias e, enfim, o envio de Cristo, o Verbo, que personifica na sua encarnação o diálogo salvífico aberto pelo Pai: "o diálogo entre Deus e o homem é tornado

\footnotetext{
${ }^{5}$ Idem, ib. p. 12.

${ }^{6}$ PAOLO VI. "Ricerca amorosa di Dio: questione capitale per l'esito dell'Anno Santo". In: Insegnamenti di Paolo VI, vol. XIII. Roma: TPV, 1975, p. 1233.

7 JOÃO PAULO II. "Catequeses sobre o Pai: A relação de Jesus com o Pai, revelação do mistério trinitário" (10.03.1999) n. 3. Disponível em: <http://w2.vatican.va/content/john -paul-ii/pt/audiences/1999/documents/hf_jp-ii_aud_10031999.html $>$. Acesso em 08 de novembro de 2015.

${ }^{8}$ PAULO VI. Encíclica “Eccesiam suam”. Petrópolis: Vozes, 1965 (sigla ES).
} 
possível em Jesus Cristo" 9 . Com dimensões universais, este diálogo divinohumano inclui também as religiões, quando o ser humano tenta responder à manifestação de Deus e entra misteriosamente na dinâmica de um colóquio sobrenatural, guiado pela graça (cf. ES 41). Porém, é em Cristo - o FilhoPalavra - que a paternidade de Deus mostra seu máximo sentido salvífico. Nele, Deus se aproxima de nós como Pai nosso:

Agora sabemos que Deus é Pai. Pai por sua própria natureza divina, em si mesmo, na geração do Verbo, seu Filho unigênito. E, por isso, Pai daquele Jesus que se fez homem; homem como nós e homem para nós; nosso semelhante, nosso irmão. Portanto - ainda que num sentido diverso, mas essencial analogicamente - Deus é também Pai nosso. ${ }^{10}$

Aqui se enraíza também a missão da Igreja: testemunhar o amor do Pai no anúncio e no diálogo com todos os povos (cf. EN 6, 25 e 53). Hoje, constatamos que a intuição de Paulo VI contribuiu para uma soteriologia em chave dialógica, ajudou no discernimento do lugar das religiões no plano da salvação e, acima de tudo, vinculou a historia salutis (una e universal) à iniciativa do Pai ${ }^{11}$, "o qual deseja que todos os homens se salvem e cheguem ao conhecimento da verdade" (1Tm 2,4). O mesmo sentido salvífico da paternidade divina é considerado por João Paulo II: o Papa reafirma o diálogo de salvação aberto pelo Pai (cf. DVi 34) ${ }^{12}$, atesta a centralidade cósmico-salvífica de Jesus, por quem o Pai estabelece seu Reino (cf. RH 1, 8, 13; RM 12-20) ${ }^{13}$, e revalida o mandato missionário ad gentes em sintonia com a paternidade universal de Deus (cf. RH 12; RM 31-40). No conjunto da reflexão, João Paulo II acentua sobretudo a misericórdia divina: definida como amor libertador e regenerador do Pai, ela está no centro da missão

\footnotetext{
${ }^{9}$ PAOLO VI. "La preghiera del Signore: nostra forza, nostra fiducia, nostra speranza". In: Insegnamenti di Paolo VI, vol. XIV. Roma: TPV, 1976, p. 510.

${ }^{10}$ PAOLO VI. "Il natale di Gesù, rivelazione della paternità di Dio", op. cit., 1974, p. 13.

${ }^{11}$ Paulo VI propôs o diálogo como categoria teológica altamente relevante. O diálogo salvífico é citado pelo Concílio Vaticano II (Gaudium et spes 92, Ad gentes 11, Nostra aetate 2), atravessa a teologia mais recente e reaparece, de modo explícito, no Documento Diálogo e Anúncio 38 e 80.

12 JOÃO PAULO II. Carta encíclica “Dominum et vivificantem”. São Paulo: Paulinas, 1986 (sigla DVi).

${ }^{13}$ Respectivamente: JOÃO PAULO II. Encíclica "Redemptor hominis". São Paulo: Paulinas, 1979 (sigla RH); e Carta encíclica "Redemptoris missio". São Paulo: Paulinas, 1991 (sigla RM).
} 
messiânica do Filho de Deus e, por conseguinte, da missão da Igreja (cf. DM 4-6) ${ }^{14}$.

Voltando-se ao "Deus rico em misericórdia" (Ef 2,4) e usando um enfoque trinitário, Papa Wojtyla reafirma a iniciativa do Pai no plano redentor: a salvação brota do "dar-se salvífico do Pai no Filho e no Espírito Santo" (DVi 11); "consiste em crer e acolher o mistério do Pai e do seu amor, que se manifesta e oferece em Jesus, por meio do Espírito Santo" (RM 12); é desígnio "realizado pelo Pai na história, por Cristo, em virtude da obra do Espírito" $"$. Pois...

Deus - tal como Cristo o revelou - não permanece apenas em estreita relação com o mundo, como Criador e fonte última da existência. Ele é também Pai: está unido ao homem por ele chamado à existência no mundo visível, mediante um vínculo ainda mais profundo que o vínculo da criação: é o amor, que não só cria o bem, mas faz com que se participe na própria vida de Deus, Pai, Filho e Espírito Santo. Efetivamente, quem ama deseja dar-se a si próprio. (DM 7)

Lidos lado a lado, os dois Papas convergem na perspectiva de fundo: a salvação tem origem paterna (nasce ex Patre), arquitetura messiânica (centrada in Christo) e dinamismo pneumatológico (dá-se per Spiritum Sanctum).

\section{Deus Pai, mistério revelado}

Quanto à manifestação do Pai na história da salvação, observamos que os dois Papas ensinam que esta deu-se gradualmente, até sua explicitação em Jesus de Nazaré. Quando Paulo VI trata da revelação de Deus Pai, parte de sua comunicação universal (mediante o salutis colloquium), considera a eleição de Israel e alcança a manifestação do Verbo Encarnado:

As páginas do Antigo Testamento já atribuíam a Deus o título de Pai do povo escolhido, por causa da sua eleição por parte de Deus, e pela íntima

\footnotetext{
${ }^{14}$ JOÃO PAULO II. Carta encíclica “Dives in misericordia”. São Paulo: Paulinas, 1981(sigla $\mathrm{DM})$.

${ }^{15}$ JOÃO PAULO II. "Catequeses sobre o Pai: Escatologia universal, a humanidade a caminho do Pai” (26.05.1999) n. 1. Disponível em: <http://w2.vatican.va/content/john-paul-ii/pt/ audiences/1999/documents/hf_jp-ii_aud_26051999.html $>$. Acesso em 08 de novembro de 2015.
} 
relação religiosa que Ele quis estabelecer com tal povo. Mas no Evangelho este apelativo de Pai, referido a Deus por Jesus, se torna habitual, normal, e adquire uma plenitude na qual se concentra não só toda a teologia, mas também a espiritualidade da verdadeira religião. ${ }^{16}$

Daqui ele conclui que em Deus há uma "paternidade transcendente, transbordante de metafísico amor e sobrenatural caridade" 17 .

João Paulo II, por sua vez, emitiu um ensino mais pontuado: parte de sua trilogia trinitária $(\mathrm{DM}, \mathrm{RH}, \mathrm{DVi})^{18}$, passa pelas Catequeses sobre o $C_{r e d o}{ }^{19}$ e chega às Catequeses sobre o Pai, em que trata da revelação da paternidade divina especificamente ${ }^{20}$. O trajeto segue a narração bíblica da historia salutis, com a progressiva revelação do Pai e seu amor desde o Antigo ao Novo Testamento, detalhando seus passos: paternidade divina em sentido amplo, relativa às criaturas; paternidade de eleição para com Israel e visível nas gestas salvadoras do Deus da Aliança; paternidade provada no zelo e misericórdia de Deus; finalmente, paternidade em sentido pleno (ontológico e salvífico), revelada no Filho Jesus ${ }^{21}$. Disto resulta uma convicção de fé: de Israel a Cristo, temos a "progressiva auto-manifestação na História do único e verdadeiro Deus" 22 . Assim se afirma o caráter revelado da Primeira Aliança e das profecias de Israel, em cujo terreno Jesus caminhou para nos dar o pleno conhecimento de Deus:

Cristo revela o Pai na mesma perspectiva, contando com um terreno já preparado, como o demonstram numerosas páginas dos escritos do Antigo Testamento. Como remate desta revelação, na véspera de sua

\footnotetext{
${ }^{16}$ PAOLO VI. "Il natale di Gesù, rivelazione della paternità di Dio", op. cit., 1974, p. 13.

${ }^{17}$ PAOLO VI. "Messaggio per la quarta Giornata Mondiale della Pace". In: Insegnamenti di Paolo VI, vol. VIII. Roma: TPV, 1970, p. 1432.

${ }^{18}$ Sobretudo a encíclica Dives in misericordia como um todo; mas também Redemptor hominis 4-8 e Dominum et vivificantem 1, 8 e 22.

${ }^{19} \mathrm{Cf}$. as Catequeses sobre o Creio, especialmente a respeito de Deus Pai. Cf. edição portuguesa: JOÃO PAULO II. Creio em Deus Pai todo-poderoso. Lisboa: Edições Paulistas, 1988.

${ }^{20}$ Referimo-nos aqui às Catequeses sobre o Pai como um todo, realizadas em 1999.

${ }^{21}$ Nestas Catequeses sobre o Pai os respectivos temas, são: A paternidade de Deus no Antigo Testamento (20.01.1999), A experiência do Pai em Jesus de Nazaré (3.03.1999) e Conhecer o Pai (17.03.1999), disponíveis online como indicamos nas referências, ao final deste artigo.

22 JUAN PABLO II. "El Dios de nuestra fe" n. 2. Disponível em: $<$ http://w2.vatican.va/content/ john-paul-ii/es/audiences/1985/documents/hf_jp-ii_aud_19850724.html $>$. Acesso em 20 de março de 2016.
} 
morte, ele diz ao apóstolo Filipe aquelas memoráveis palavras: "Há tanto tempo que estou convosco e tu não me conheces? Quem me vê, vê o Pai" (Jo 14,9). (DM 5)

Em Jesus esta revelação não apenas se plenifica, mas se abre universalmente: diante da humanidade inteira, de todas as culturas e tempos, Jesus é e será sempre a visio Patris, como diz Paulo: "Ícone visível do Deus invisível" (Col 1,15). Paulo VI e João Paulo II o afirmam com o Apóstolo, respectivamente, nas alocuções ${ }^{23}$ e na encíclica Dives in misericordia (DM 7 e 13).

\section{O Pai em sua relação intra-trinitária}

Outro aspecto importante do magistério aqui analisado, é a consideração do mistério do Pai em sua relação intra-trinitária (pericorese), como fonte da vida divina (arché), donde provêm o Logos e o Pneuma (díade, no dizer dos orientais). Nos textos de Paulo VI, a pericorese deduz-se de uma indicação: o salutis colloquium que o Pai nos oferece na economia, aponta para o amoris colloquium que ele estabelece eternamente com o Filho, pelo Espírito, na imanência. Em seu mistério, o Pai é amor fontal: dele nos vem o Filho Unigênito, em cujo nome nos é enviado o Espírito Santo. Paulo VI cita, a propósito, esta passagem de João: "O Espírito Santo, que o Pai enviará em meu nome, vos ensinará todas as coisas e vos recordará tudo o que eu vos tiver dito" (Jo 14,26 apud ES 10). E prossegue: "Este Espírito é, portanto, Dom do Pai para a nossa regeneração e adoção filial: com ele clamamos a Deus $A b b a ́$, Pai (Rm 8,15; Gl 4,6)" (ES 18).

Pronunciando-se num outro contexto, João Paulo II retoma com particulares ênfases estes enunciados. $\mathrm{O}$ amor do Pai é considerado primus fons da vida divina e de toda bênção para as criaturas (cf. RH 20 e DVi 54, respectivamente). Ele pondera:

Sobre esta base a fé cristã compreende a igualdade das três Pessoas divinas: o Filho e o Espírito são iguais ao Pai não como princípios autônomos, como se fossem três deuses, mas enquanto recebem do

${ }^{23}$ Cf. PAOLO VI. Gli insegnamenti del ciclo liturgico. In: Insegnamenti di Paolo VI, vol. V. Roma: TPV, 1967, p. 685. 
Pai toda a vida divina, distinguindo-se d'Ele reciprocamente só na diversidade das relações. ${ }^{24}$

Sendo de fato amor, Deus é desde sempre Pai que se dá inteiramente ao gerar o Filho, ambos unidos numa comunhão de amor que é o Espírito Santo. Esta distinção e compenetração (pericorese) das três Pessoas divinas não se acrescenta à sua unidade, mas é a sua expressão mais profunda e caracterizadora. ${ }^{25}$

Explicitando este "dar-se inteiramente" do Pai - segundo o amor que O constitui essencialmente (cf. 1Jo 4,8) - João Paulo II define a salvação como se donare de Deus Pai no Filho e no Espírito (DVi 11). Estes conferem um "duplo ritmo" (DVi 63) à obra da salvação, que nasce do desígnio do Pai. Filho e Espírito participam (sem confusão, substituição ou subordinação) da revelação-salvação decretada pelo Pai, o qual é um só Deus com eles segundo a ousía; e ao mesmo tempo a hipóstase primeira, segundo a táxis ${ }^{26}$. Disto se colhe, ainda, o caráter relacional das Pessoas divinas na unidade do "Deus uno e trino, que existe em si mesmo como realidade transcendente de Dom inter-pessoal" (DVi 59).

\section{O Pai, arché da vida divina}

Considerando particularmente a pessoa do Pai nas relações intra-divinas, o magistério de Paulo VI e João Paulo II retoma e convalida a monarchia Patris, segundo a antiga tradição da Igreja: a afirmação conceitualmente clara e dogmaticamente coerente de que o Pai é a única arché ou único principium sine principio da vida divina. Donde a composição monos (uma só) com arché (fonte ou princípio), esclarecendo a origem paterna do Logos gerado e do

\footnotetext{
24 JOÃO PAULO II. "Catequeses sobre o Pai: A relação de Jesus com o Pai, revelação do mistério trinitário" (10.03.1999) n. 3. Disponível em: <http://w2.vatican.va/content/john -paul-ii/pt/audiences/1999/documents/hf_jp-ii_aud_10031999.html $>$. Acesso em 08 de novembro de 2015.

${ }^{25}$ JOÃO PAULO II. "Catequeses sobre o Pai: O diálogo com o Islão” n. 3. Disponível em: <http:// w2.vatican.va/content/john-paul-ii/pt/audiences/1999/documents/hf_jp-ii_aud_05051999. html>. Acesso em 02 de Abril de 2016.

${ }^{26}$ Cf. LADARIA, L. F. El Dios vivo y verdadero. Salamanca: Ed. Secretariado Trinitario, 1998, p. 345 .
} 
Pneuma espirado ${ }^{27}$, pois ambos procedem do Pai como que de um mesmo Princípio. Paulo VI diz:

Primeiro Ser, necessário, absoluto, infinito e eterno, Deus se qualifica Pai, e o é pela geração do Filho unigênito, Deus de Deus, e pela nossa geração adotiva mediante Cristo, no sopro do Espírito Santo. ${ }^{28}$

\section{E João Paulo II acrescenta:}

Partindo do Filho, a reflexão do Novo Testamento e, depois, da teologia nela arraigada, aprofundaram o mistério da paternidade de Deus. O Pai é Aquele que na vida trinitária constitui o princípio absoluto, Aquele que não tem origem e do qual provém a vida divina. A unidade das três Pessoas é partilha da única essência divina, mas no dinamismo de relações recíprocas que, no Pai, têm a fonte e o fundamento: é o Pai que gera, o Filho que é gerado, o Espírito Santo que procede. ${ }^{29}$

\section{Com efeito, como diz Ladaria:}

[...] somente o Pai é fonte, por mais que seja verdade que sem o Filho e o Espírito que procedem desta fonte não pode o Pai receber tal nome. É preciso afirmar as duas coisas: o Pai é a única fonte e princípio da divindade e, ao mesmo tempo, não existe nem pode existir sem o Filho e o Espírito, estando referido a Eles como o Filho e o Espírito estão referidos a Ele. ${ }^{30}$

Mesmo que se busque outra linguagem para expressar as relações trinitárias sem romper a unidade substancial de Deus, a Trindade permanece inefável e como tal deve ser contemplada pela teologia, como nos adverte Lossky:

A teologia será fiel à tradição até o ponto em que as suas expressões técnicas - ousía, hipóstase, consubstancialidade, relações de origem, causalidade,

${ }^{27}$ Conforme linguagem trinitária dos Padres da Igreja e dos Concílios, como lemos em DZ 150, 490, 525, 527, 804, 805 e 1331, na edição italiana de 1995.

${ }^{28}$ PAOLO VI. "Il natale di Gesù, rivelazione della paternità di Dio", op. cit., 1974, p. 14.

29 "Catequeses sobre o Pai: A relação de Jesus com o Pai, revelação do mistério trinitário" n. 2. Disponível em: <http://w2.vatican.va/content/john-paul-ii/pt/audiences/1999/documents/ hf_jp-ii_aud_10031999.html>. Acesso em 08 de novembro de 2015. Aqui João Paulo II cita, nas linhas finais, o IV Concílio Lateranense (cf. DZ 804, na edição italiana de 1995).

${ }^{30}$ LADARIA, L. F. op. cit., 1998, p. 312 
monarchia - servirem a evidenciar este grande mistério inicial do DeusTrindade, sem ofuscá-lo com "deduções trinitárias" a partir de um outro princípio. $^{31}$

Importa, pois, que se esclareça o que é tradicionalmente afirmado no Oriente e no Ocidente: admitir o Pai como arché da vida trinitária não significa qualquer sucessão temporal das hipóstases entre si, nem subordinação do Filho ou do Pneuma ao Pai, pois Filho e Espírito são co-eternos e co-divinos, em comunhão com o Pai ingênito. Ou seja: a monarchia Patris solicita a pericorese, de modo que - bem compreendidas - uma corrobora a outra. Além disso, ainda que se encontrem outros termos para expressar tal mistério, "não se exclui que seja próprio do Pai o amor e a doação originais, aos quais o Filho e o Espírito correspondem, cada um a seu modo"32. Afinal, como observa Harrison, o Pai é pai em sua original e eterna doação, no Verbo proferido e no Pneuma espirado:

O Pai gera o Filho e espira o Espírito Santo enchendo-os de tudo aquilo que ele é, dando-lhes toda a sua divindade, a sua glória, o seu poder criador, toda a sua autoridade. Deixa-os agir segundo a sua vontade para criar, manter e aperfeiçoar o universo. Quer que o Filho e o Espírito Santo o apresentem ao mundo, revelando-o. O Pai nada retém para si, mas partilha e dá a eles tudo o que possui. A grandeza deles é motivo de sua glória, enquanto Pai. ${ }^{33}$

Neste sentido, Paulo VI fala da "capacidade de doação" (EN 28) própria do amor divino, seguido por João Paulo II que usa a expressão "doação paterna" (RH 20). Certamente a convalidação da monarchia Patris nos ajuda a elucidar a questão do Filioque ${ }^{34}$, aproximando-nos da teologia ortodoxa que - ao defender a processão do Espírito ek monoû tô̂ Patrós (do único Pai) -

[...] professa a própria fé na Trindade simples, na qual as relações de origem designam a diversidade absoluta dos Três e, ao mesmo tempo,

\footnotetext{
${ }^{31}$ LOSSKY, V. A immagine e somiglianza di Dio. Bologna: EDB, 1999, p. 126.

${ }^{32}$ LADARIA, L. F. op. cit., 1998, p. 311.

${ }^{33}$ HARRISON, N.V. "Un approccio ortodosso al mistero della Trinità". Concilium 1 (2001), p. 83.

${ }^{34}$ Cf. PONTIFICIO CONSIGLIO PER L'UNITÀ DEI CRISTIANI. "La procéssion du Saint-Esprit”. In: Enchiridion Vaticanum vol. 14. Bologna: EDB, 1995, pp. 1726-1747.
} 
indicam a unidade deles representada pelo Pai, que não é apenas mônada mas, enquanto Pai, é o princípio da una Tríade. ${ }^{35}$

Ao nosso ver, contudo, a grande verdade preservada pela monarchia Patris é o caráter doativo e gratuito do amor do Pai, que "se revelou e se deu a nós por adoção", abrindo nossos olhos à "visão ofuscante e fascinante da paternidade de Deus" ${ }^{36}$. "Porque o Pai é a primeira fonte e o doador da vida, desde o princípio" (RH 20).

\section{O Pai como amor fontal na Trindade}

O caráter relacional, doativo e gratuito do Pai desvela sua natureza profunda e simples: "Deus é Amor" (1João 4,8). Paulo VI diz que a paternidade e o amor, em Deus, são verdades conexas: Deus é Pai e Deus é amor sintetizam numa "visão complexiva e orgânica" ${ }^{37}$ toda a revelação cristã. É, aliás, o que Jesus nos ensina com a prece do Pai-nosso, introduzindo-nos na intimidade d'Aquele "que nos amou primeiro" (1Jo 4,19). Assim nos diz o pontífice:

Pai nosso, que estás nos céus! (Mt 6,9). Eis, pois, a grande conquista, cujas dimensões nós jamais conseguiremos explorar suficientemente: Deus é Pai! Este conceito existencial, metafísico, único, original e inefável, é a fonte da nossa religião, a qual reza este princípio: se Deus é Pai, Deus é Amor. Portanto, Ele nos ama. Nossas aspirações mentais, afetivas e espirituais só serão saciadas, quando esta convicção penetrar o nosso espírito: nós somos amados; amados por Deus! Tudo parece bem para nós, se Deus nos ama. E de fato é assim. Eis aqui a solução (potencial, ao menos) para o nosso problema: se Deus me ama, eu não posso deixar de amá-Lo. A caridade de Deus para conosco nos envolve e - em virtude do que sua graça nos possibilita realizar - ressoa forte, sincera, humana e feliz, na resposta que a Ele damos: sim, ó Senhor, eu também, Tu bem o sabes, eu também Te amo! Todo o resto, virá por si mesmo. ${ }^{38}$

\footnotetext{
${ }^{35}$ LOSSKY, V. Ibidem.

${ }^{36}$ PAOLO VI. "Il natale di Gesù, rivelazione della paternità di Dio", op. cit., 1974, p. 13

${ }^{37}$ PAOLO VI. "La rivelazione dell'amore di Dio, cardine portante della nostra concezione religiosa". In: Insegnamenti di Paolo VI, vol. XIII, 1975, p. 890.

${ }^{38}$ PAOLO VI. "Ricerca amorosa di Dio: questione capitale per l'esito dell'Anno Santo", op. cit., 1975, p. 1233.
} 
Na fé em Deus-Amor está "toda a teologia da salvação, o mais profundo mergulho que nossa introspecção pode fazer no coração mesmo de Deus" 39 .

Seguindo em direção semelhante, João Paulo II insiste na verdade sobre Deus Caritas à luz das Escrituras. Trata-se de um enfoque teológico próximo àquele feito por Pfammatter, na esteira do Concílio Vaticano II: afirmar que "Deus é agàpe significa que Ele é, por sua natureza, amor que se abaixa, que se volta aos homens, que os redime e, assim, os conduz à sua própria autenticidade" ${ }^{40}$. De fato, João Paulo II partilha desta mesma compreensão, ao afirmar o sentido relacional e oblativo da caritas Dei:

Este amor é capaz de debruçar-se sobre todos os filhos pródigos, sobre qualquer miséria humana e, especialmente, sobre toda miséria moral, sobre o pecado. (DM 6)

Por outro lado, sendo que em Deus o agir segue o ser de modo perfeito e sem contradições, esta manifestação do Pai na oeconomia nos permite vislumbrar o amor de relação-comunhão que o constitui na immanentia: o Deus unitrino é, em seu mistério, uma "realidade transcendente de Dom interpessoal" (DVi 59). Daí o fato de João Paulo II conceber a salvação como o se donare gratuito e comunional do Pai, perceptível na obra da criação, na aliança com Israel e, mais ainda, na kênosis de seu Filho (cf. DVi 11-14): "Pois Deus amou tanto o mundo, que entregou o seu Filho único, para que todo o que nele crê não pereça, mas tenha a vida eterna" (Jo 3,16 ) - argumento presente em Paulo VI (cf. ES 42) e João Paulo II (cf. RH 1). Os dois Papas ecoam, a seu modo, a afirmação do fontalis amor do Pai na comunhão trinitária, princípio da economia salvífica, como diz o Concílio Vaticano II:

Este desígnio [de salvação] provém do "amor fontal" ou da caridade de Deus Pai, que é Princípio sem Princípio e do qual é gerado o Filho e pelo filho procede o Espírito santo. Por nímia misericórdia e bondade Sua nos criou livremente e, além disso, nos chamou gratuitamente à comunhão de Sua vida e Sua glória. Generosamente difundiu a divina bondade e não cessa de difundi-la. Criador do universo, tornar-se-á "tudo em todas as

${ }^{39}$ PAOLO VI. “Amare il mondo come c'insegna il Vangelo". In: Insegnamenti di Paolo VI, vol. XV. Roma: TPV, 1977, p. 161.

${ }^{40}$ PFAMMATTER, J. "Propiedades y formas de actuación de Dios en el NT”. In: FEINER, J.; LÖHRER, M. Mysterium salutis II. $2^{\text {a }}$ ed. Madrid: Ediciones Cristiandad, 1977, p. 244. 
coisas" (1Cor 15,28), procurando ao mesmo tempo Sua glória e nossa alegria. (AG 2) $)^{41}$

\section{Considerações finais}

O ensino de Paulo VI e de João Paulo II sobre Deus Pai nos proporciona um aprofundamento pedagógico do que professamos no credo apostólico: Creio em Deus Pai todo-poderoso. Pedagógico no sentido de conduzir à verdade crida, propondo a doutrina trinitária em seus termos mais fundamentais. Ensinar neste nível magisterial é uma tarefa permanente para um pontífice; mas teve particular importância após o Concílio Vaticano II, quando foram ensaiados diferentes modelos teológicos e se efetuou a reforma do curriculum de estudos da teologia dogmática. A chamada teologia dos manuais foi revista e o discurso sobre a Trindade, remodelado ${ }^{42}$. A Cristologia evoluiu, com corpo próprio ao lado dos tratados De Deo Uno e De Deo Trino. Na trilha, cresce paulatinamente a pneumatologia, abordando a pessoa e missão do Espírito Santo num discurso sistemático ${ }^{43}$.

Lendo hoje o magistério desses dois Papas pós-conciliares, apreendemos que tais ajustes de método e discurso não implicam (nem deveriam implicar) uma ausência ou preterimento da theologia Patris. Antes, era preciso aprofundála e ressituá-la no horizonte da triadologia, na qual as teologias do Pai, do Filho e do Espírito se encontram num mesmo nível de importância e conjuntamente implicadas na obra da salvação. Neste sentido, tanto Paulo VI quanto João Paulo II pensam trinitária e salvificamente a questão da primeira Pessoa divina, colaborando para uma teologia trinitário-econômica de Deus Pai.

Notemos que a exposição conceitual dos dois Papas não se perde na especulação, mas se mostra engajada em dois compromissos: de um lado, a

${ }^{41}$ CONCÍLIO VATICANO II. "Decreto Ad gentes sobre a atividade missionária da Igreja" n. 2. In: Compêndio do Vaticano II. 14ª ed. Petrópolis: Vozes, 1980, p. 352.

42 Em 1967, há dois anos do Concílio, Karl Rahner publica suas propostas de método e estrutura do tratado De Deo Trino. Já naquele momento o autor se referia às linhas fundamentais do magistério sobre a Trindade, para desembocar numa nova síntese sistemática. Cf. RAHNER, K. "Il Dio trino come fondamento originario e trascendente della storia della salvezza". In: FEINER, J.; LÖHRER, M. Mysterium salutis 3. Brescia: Queriniana, 1969, pp. 402-502.

${ }^{43}$ Dentre muitas publicações representativas deste esforço, consideramos emblemáticas as coleções Mysterium salutis (Freiburg im Breisgau: Herder), Cogitatio Fidei (Paris: Les Éditions du Cerf) e Biblioteca di Teologia Contemporanea (Brescia: Queriniana). Esta última se estendeu por décadas, publicando teólogos europeus, norte-americanos e latino-americanos. 
recepção eclesial da revelação da Trindade; de outro, os alcances salvíficos desta mesma Revelação. Afinal, esses dois compromissos se conectam na grande agenda da evangelização, desde Evangelii nuntiandi (Paulo VI) até Redemptoris missio (João Paulo II), tendo o Pai por fonte e princípio, em seu amor de misericórdia pela humanidade.

Do primeiro compromisso, destacamos o teor catequético dos enunciados, a referência ao Concílio Vaticano II e a preocupação com o Filioque na busca da plena comunhão com as Igrejas ortodoxas do Oriente. Bem compreendida, a paternidade universal de Deus dimensiona a economia sacramental, a dignidade do ser humano imago Dei e a proposta de uma evangelização dialógica e inclusiva em face das religiões não-cristãs. Não por acaso, os dois pontífices valorizam o diálogo (salutis colloquium) como categoria teológica. Quanto ao Filioque, a correta ponderação entre monarchia Patris e pericorese ajuda a distinguir e a articular as perspectivas oriental e ocidental: uma focada na fontalidade do Pai, a outra focada na reciprocidade entre o Pai e o Filho no Espírito, como o demonstra a Clarificatio do Pontifício Conselho para a Unidade dos Cristãos ${ }^{44}$. Este documento deixa claro que os bizantinos entendem "processão" em sentido ontológico (ekpòreusis), professando com os latinos o Pai como única arché (princípio sem princípio) da vida intratrinitária, donde o Paráclito toma origem eternamente (cf. Jo 15,26). De fato, ontologicamente não pode haver duas arché na Trindade, como se o Filho fosse autonomamente (sem o Pai) o princípio do Pneuma. Já os latinos entendem "processão" em sentido econômico (processio), referindo-se à missão do Espírito na história da salvação, como Amor do Pai e do Filho enviado ao mundo. Além disso, os latinos sempre afirmaram que o Espírito procede a Patre (do Pai) principaliter (como de um só Princípio). Assim, como mencionamos acima, a "reciprocidade" da perspectiva latina (econômica) não fere a "fontalidade" da perspectiva bizantina (ontológica), permitindo que as duas ênfases de complementem ${ }^{45}$.

Do segundo compromisso, destacamos a extensão trinitário-econômica da paternidade divina, importante para a reta confissão de Deus Trino e a prática missionária nos contextos de diálogo inter-religioso. Paulo VI inclui as religiões no "diálogo longo e variado" entre Deus e a humanidade (cf. ES 41) e volta-se aos

\footnotetext{
${ }^{44}$ Cf. PONTIFICIO CONSIGLIO PER L'UNITÀ DEI CRISTIANI. Op. cit., 1995, p. 17261747.

${ }^{45}$ Cf. Idem, ib. p. 1733-1735.
} 
[...] adoradores de Deus segundo o conceito da religião monoteísta, especialmente da muçulmana, dignos de admiração pelo que há de verdadeiro e de bom no culto que prestam a Deus. (ES 60)

Três décadas mais tarde, João Paulo II volta ao tema durante suas Catequeses sobre o Pai, ao tratar do diálogo com os Islã:

Desejaria hoje retomar aquilo que, há alguns anos, eu disse aos jovens muçulmanos em Casablanca: "Nós cremos no mesmo Deus, o Deus único, o Deus vivo, o Deus que cria os mundos e leva as suas criaturas à própria perfeição" (L'Osservatore Romano, ed. port. de 15.09.1995, p. 10). O patrimônio dos textos revelados da Bíblia fala com voz unânime da unicidade de Deus. Jesus mesmo o reafirma, fazendo sua a profissão de Israel: "O Senhor, nosso Deus, é o único Senhor" (Mc 12, 29; cf. Dt 6, 4-5). É a unicidade afirmada também nestas palavras de louvor, que brotam do coração do apóstolo Paulo: "Ao Rei dos séculos, imortal, invisível, Deus único, honra e glória pelos séculos dos séculos. Amém" $(1 \mathrm{Tm} 1,17) .{ }^{46}$

As relações do Pai, do Filho e do Espírito Santo não atenuam de modo algum a unidade divina, como explica o IV Concílio Lateranense: "Cada uma das três Pessoas é aquela Realidade, isto é, substância, essência ou natureza divina. Ela não gera, não é gerada nem procede" ${ }^{47}$. A doutrina cristã sobre a Trindade, ratificada pelos Concílios, é explícita na rejeição de qualquer triteísmo ou politeísmo. No que se refere à única substância divina, há uma significativa correspondência entre Cristianismo e Islã, como argumenta João Paulo II:

Essa correspondência, porém, não deve fazer esquecer as diversidades entre as duas religiões. Com efeito, sabemos que a unidade de Deus se exprime no mistério das três Pessoas divinas. Sendo de fato Amor (cf. 1Jo 4, 8), Deus é desde sempre Pai que Se dá inteiramente ao gerar o Filho, ambos unidos numa comunhão de amor que é o Espírito Santo. Esta distinção e compenetração (pericorese) das três Pessoas divinas

${ }^{46}$ JOÃO PAULO II. "Catequeses sobre o Pai: O diálogo com o Islão"n. 1. Disponível em: $<$ http:// w2.vatican.va/content/john-paul-ii/pt/audiences/1999/documents/hf_jp-ii_aud_05051999. html>. Acesso em 02 de Abril de 2016.

${ }^{47}$ DENZINGER, H. Op. cit., 1995, n. 804. 
não se acrescenta à sua unidade, mas é a sua expressão mais profunda e caracterizadora. ${ }^{48}$

Assim abrem-se para nossa tarefa teológica os horizontes de aplicação da theologia Patris, que atualiza as antigas fórmulas com vistas ao testemunho e ao anúncio da paternidade de Deus a todos os povos, em atitude dialógica e inclusiva.

\section{Referências bibliográficas}

CONCÍLIO VATICANO II. Compêndio do Vaticano II: constituições, decretos, declarações. $14^{\mathrm{a}}$ ed. Petrópolis: Vozes, 1980.

CONCÍLIO VATICANO II. "Constituição pastoral Gaudium et spes sobre a Igreja no mundo de hoje". In: Compêndio do Vaticano II. $14^{\mathrm{a}}$ ed. Petrópolis: Vozes, 1980, pp. 141-256.

CONCÍLIO VATICANO II. "Decreto Ad gentes sobre a atividade missionária da Igreja". In: Compêndio do Vaticano II. 14 a ed. Petrópolis: Vozes, 1980, pp. 349-399.

CONCÍLIO VATICANO II. "Declaração Nostra aetate sobre as relações da Igreja com as religiões não-cristãs". In: Compêndio do Vaticano II. 14a ed. Petrópolis: Vozes, 1980, pp. 617-625.

DENZINGER, H. Enchiridion Symbolorum: magistero della chiesa. $37^{\mathrm{a}}$ ed. Bologna: EDB, 1995.

HARRISON, N.V. "Un approccio ortodosso al mistero della Trinità". Concilium 1 (2001), pp. 79-89.

JOÃO PAULO II. Carta encíclica "Dives in misericordia”. São Paulo: Paulinas, 1981.

JOÃO PAULO II. Carta encíclica “Dominum et vivificantem”. São Paulo: Paulinas, 1986.

JOÃO PAULO II. Carta encíclica “Redemptoris missio”. São Paulo: Paulinas, 1991.

\footnotetext{
${ }^{48}$ JOÃO PAULO II. "Catequeses sobre o Pai: O diálogo com o Islão" n. 3. Disponível em: $<$ http:// w2.vatican.va/content/john-paul-ii/pt/audiences/1999/documents/hf_jp-ii_aud_05051999. html>. Acesso em 02 de Abril de 2016.
} 
JOÃO PAULO II. Creio em Deus Pai todo-poderoso. Lisboa: Edições Paulistas, 1988. Edição portuguesa que reúne todas Catequeses sobre o Creio de João Paulo II.

JOÃO PAULO II. Encíclica “Redemptor hominis”. São Paulo: Paulinas, 1979.

JOÃO PAULO II. Encíclicas de João Paulo II. São Paulo: Paulinas, 1997.

JOÃO PAULO II. "Catequeses sobre o Pai: A paternidade de Deus no Antigo Testamento"(20.01.1999). Disponível em: <http://w2.vatican.va/content/ john-paul-ii/pt/audiences/1999/documents/hf_jp-ii_aud_20011999. html $>$. Acesso em 08 de novembro de 2015.

JOÃO PAULO II. "Catequeses sobre o Pai: A experiência do Pai em Jesus de Nazaré" (3.03.1999). Disponível em: <http://w2.vatican.va/content/ john-paul-ii/pt/audiences/1999/documents/hf_jp-ii_aud_03031999. html $>$. Acesso em 08 de novembro de 2015.

JOÃO PAULO II. "Catequeses sobre o Pai: A relação de Jesus com o Pai, revelação do mistério trinitário" (10.03.1999). Disponível em: <http:// w2.vatican.va/content/john-paul-ii/pt/audiences/1999/documents/hf_jpii_aud_10031999.html $>$. Acesso em 08 de novembro de 2015.

JOÃO PAULO II. "Catequeses sobre o Pai: A relação de Jesus com o Pai, revelação do mistério trinitário" (10.03.1999). Disponível em: <http:// w2.vatican.va/content/john-paul-ii/pt/audiences/1999/documents/hf_jpii_aud_10031999.html $>$. Acesso em 08 de novembro de 2015.

JOÃO PAULO II. "Catequeses sobre o Pai: Conhecer o Pai” (17.03.1999). Disponível em: <http://w2.vatican.va/content/john-paul-ii/pt/audiences/1999/documents/hf_jpii_aud_17031999.html>. Acesso em 08 de novembro de 2015.

JOÃO PAULO II. "Catequeses sobre o Pai: O diálogo com o Islão" (05.05.1999). Disponível em: <http://w2.vatican.va/content/john-paulii/pt/audiences/1999/documents/hf_jp-ii_aud_05051999.html>. Acesso em 02 de Abril de 2016.

JOÃO PAULO II. "Catequeses sobre o Pai: Escatologia universal, a humanidade a caminho do Pai” (26.05.1999). Disponível em: <http:// w2.vatican.va/content/john-paul-ii/pt/audiences/1999/documents/hf_jpii_aud_26051999.html >. Acesso em 08 de novembro de 2015. 
JUAN PABLO II. “El Dios de nuestra fe”. Disponível em: $<$ http://w2.vatican. va/content/john-paul-ii/es/audiences/1985/documents/hf_jp-ii_ aud_19850724.html >. Acesso em 20 de março de 2016.

LADARIA, L. F. El Dios vivo y verdadero. Salamanca: Ed. Secretariado Trinitario, 1998.

LOSSKY, V. A immagine e somiglianza di Dio. Bologna: EDB, 1999.

PAOLO VI. "Gli insegnamenti del ciclo liturgico". In: Insegnamenti di Paolo VI, vol. V. Roma: TPV, 1967, pp. 684-686.

PAOLO VI. "Messaggio per la quarta Giornata Mondiale della Pace". In: Insegnamenti di Paolo VI, vol. VIII. Roma: TPV, 1970, pp. 1427-1432.

PAOLO VI. "Il natale di Gesù, rivelazione della paternità di Dio". In: Insegnamenti di Paolo VI, vol. XII. Roma: TPV, 1974, pp. 12-14.

PAOLO VI. "La rivelazione dell'amore di Dio, cardine portante della nostra concezione religiosa". In: Insegnamenti di Paolo VI, vol. XIII, 1975, pp. 890-891.

PAOLO VI. "Ricerca amorosa di Dio: questione capitale per l'esito dell' Anno Santo. Allocuzione dell'udienza generale" (5.11.1975). In: Insegnamenti di Paolo VI, vol. XIII. Roma: TPV, 1975, pp. 1231-1233.

PAOLO VI. "La preghiera del Signore: nostra forza, nostra fiducia, nostra speranza". In: Insegnamenti di Paolo VI, vol. XIV. Roma: TPV, 1976, pp. 509-511.

PAOLO VI. “Amare il mondo come c'insegna il Vangelo". In: Insegnamenti di Paolo VI, vol. XV. Roma: TPV, 1977, pp. 160-162.

PAULO VI. Encíclica “Eccesiam suam”. Petrópolis: Vozes, 1965.

PAULO VI. Exortação apostólica "Evangelii nuntiandi”. 9a ed. São Paulo: Loyola, 1979.

PFAMMATTER, J. "Propiedades y formas de actuación de Dios en el NT". In: FEINER, J.; LÖHRER, M. Mysterium salutis II. $2^{\mathrm{a}}$ ed. Madrid: Ediciones Cristiandad, 1977, pp. 233-248.

PONTIFÍCIO CONSELHO PARA O DIÁLOGO INTER-RELIGIOSO. Documento Diálogo e Anúncio. $3^{\mathrm{a}}$ ed. São Paulo: Paulinas, 1999. 
PONTIFICIO CONSIGLIO PER L'UNITÀ DEI CRISTIANI. “La procéssion du Saint-Esprit”. In: Enchiridion Vaticanum vol. 14. Bologna: EDB, 1995, pp. 1726-1747.

RAHNER, K. "Il Dio trino come fondamento originario e trascendente della storia della salvezza". In: FEINER, J.; LÖHRER, M. Mysterium salutis 3. Brescia: Queriniana, 1969, pp. 402-502.

Marcial Maçaneiro

Doutor em Teologia pela Pontifícia Universidade Gregoriana (Roma)

Docente do Programa de Pós-Graduação "stricto sensu" em Teologia na PUC-PR

Curitiba / PR - Brasil

E-mail: marcialscj@hotmail.com

Recebido em: 01/06/16

Aprovado em: 03/08/16 